\title{
Genotype Effect of $\kappa$-Casein on Milk Performance in Japanese Black Cows
}

\author{
Tomoko Yamamoto, Kazuhiro Shimada*, Masayoshi TaKahash", \\ Toshiyuki TABATA, Naoki TaKENOUCHI ${ }^{*}$, Kazunaga OHSHIMA*, \\ Akio KIKkawa, Osamu NaKayama and Motoaki Kosugiyama \\ School of Agriculture, Ibaraki Univ,, Ami-machi, Ibaraki-ken 300-03 \\ * Chugoku National Agricultural Experiment Station, Oda-shi 694
}

(Received July 12, 1994)

Key words : $\kappa$-casein genotypes, milk performance, Japanese Black cows, PCR

The genotypes of 30 Japanese Black cows at the $\kappa$-casein loci were determined using the PCR method to examine their effect on calf growth which showed the milk performance of the dam.

\section{Materials and Methods}

Animals: Thirty Japanese Black cows derived from an experimental herd maintained at Chugoku National Agricultural Experiment Station were used in this study. These cows produced 74 calves, whose weight was used to calculate a daily gain from birth to 60 days of age. Cows were fed $20 \mathrm{~kg}$ of silage, $2 \mathrm{~kg}$ of hay and $2 \mathrm{~kg}$ of concentrate per day ${ }^{8)}$. Calves were fed hay ad libitum and a pelleted creep ration of not more than $2 \mathrm{~kg}$ per day. They were weighed within 24 hours postpartum, and thereafter weighed twice a month up to six months of age.

Determination of $\kappa$-casein genotypes: Ge- nomic DNA was prepared from the blood of 30 dams. The $P C R$ reaction was performed using $250 \mathrm{ng}$ of genomic DNA as a template $\mathrm{e}^{2)}, 200 \mu \mathrm{M}$ of each dNTP. 1 unit of Tth DNA polymerase (TOYOBO) with reaction buffer and 20 pmole of each primer. The PCR for 35 cycles was applied : denaturation at $93^{\circ} \mathrm{C}$ for $1 \mathrm{~min}$, annealing at $55^{\circ} \mathrm{C}$ for $1 \mathrm{~min}$, extention at $72^{\circ} \mathrm{C}$ for 1 min. Synthetic oligonucleotides were used as primers $^{1 \text { ) }}$ : Primer 1 (sense primer), 5' CGCTGTGAGAAAGATGAAAGATTC 3' ; Primer 2 (antisense primer), 5'AGATTCAAGGAGTATACCAATTGTTG 3'. Primer 1 was a terminal sequence of exon 4 and primer 2 was 26 nucleotides in intron 4. Therefore, the DNA fragment containing exon 4 was amplified by PCR. After amplification, $780 \mathrm{bp}$ of PCR products were digested with Hind $\mathrm{II}^{3,6)}$ and Pst $\mathrm{I}^{7)}$, and were analyzed by agarose gel electrophoresis. This procedure for determining $\kappa$-casein genotypes is almost identical to that used by

黒毛和種におけるんーカゼイン遺伝子型と泌乳性について：山本智子・島田和宏*・高橋政義* 田烟利幸・竹之内

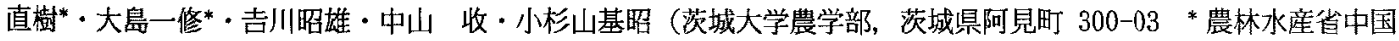
農業試鈳場，大田市 694) 
Yamamoto, Shimada, Takahashi, Tabata, Takenouchi, Ohshima, Kikkawa, Nakayama and Kosugiyama

CHIKUNi et al..$^{2)}$

Statistical methods: The data obtained in this study were analyzed by least-squares procedures $^{i)}$. The calf daily gain from birth to 60 days was analyzed according to the model including the fixed effects of $\kappa$-casein genotypes, calving season, calf sex and parity of cow and the random effect of cow within $\kappa^{-}$ casein genotypes. The effects found to be unimportant $(\mathrm{P}>0.20)$ were deleted from the final model.

\section{Results and Discussion}

PCR products had a $780 \mathrm{bp}$ sequence. Three genotypes $(\mathrm{AA}, \mathrm{AB}, \mathrm{BB})$ were determined according to the PCR of the above-mentioned regions and restriction digestion of PCR products with Hind III and PstI ( TOYOBO ). After the digestion of PCR products with Hind III, the digested fragments were observed by electrophoresis. We observed, in $\kappa$-casein genotype $\mathrm{AA}$, one band at the $780 \mathrm{bp}$ sequence ; in genotype $A B$, three bands at 780,413 and $367 \mathrm{bp}$ sequences; and in genotype $\mathrm{BB}$, two bands at 413 and $367 \mathrm{bp}$ sequences. Three genotypes could also be determined by PstI digestions. All these results are coincident with the results of CHIKun et al. ${ }^{2)}$ The distribution of $\kappa$-casein genotypes in this experiment was as follows, AA, 17 cows $(56.7 \%)$; AB, 12 cows $(40.0 \%)$; BB,
1 cow (3.3\%). The gene frequency of $\mathrm{A}$ was 0.77 and $B$ was 0.23 , respectively. The distribution of $\kappa$-casein genotypes and gene frequency in this experiment were almost the same as those reported by CHIKUNI $e t$ al. ${ }^{2)}$ and RANDO et $a l^{7)}$ We obtained data for only one BB sample, therefore, the least-square analysis of variance was done without $\mathrm{BB}$ data. The least -square means and standard error for daily gains from birth to 60 days old are presented in Table 1. The main effect of the parity number was significant $(P=0.0134)$. This shows that the calf of an AA genotype dam tends to have a higher value in daily gain from birth to 60 days than that of an $\mathrm{AB}$ genotype dam $(\mathrm{P}=$ 0.0596). Shimada et al. ${ }^{8)}$ mentioned that the milk performance of Japanese Black cows could be estimated by the calf daily gain from birth to 60 days of age. Therefore, our results suggest that AA cows produce more milk than $\mathrm{AB}$ cows. We thought that the relation between $\kappa$-casein genotypes and milk performance appeared clearly in beef cattle. In Holstein cows, Komatsu et al. ${ }^{5)}$ reported that $\kappa$ casein $\mathrm{AB}$ cows produced more milk than AA cows. This result was different from our current study, though the reason was not discovered. We must do further research on the relation between $\kappa$-casein genotypes and milk performance in other breeds.

Table 1. Least-squares means and standard errors for calf daily gain from birth to 60 days $(\mathrm{kg} / \mathrm{day})$

\begin{tabular}{lcccc}
\hline \multicolumn{1}{c}{ Effect } & & No. & $\begin{array}{c}\text { Least-squares } \\
\text { mean }\end{array}$ & Standard error \\
\hline Overall mean & & 74 & .7730 & .0280 \\
\multirow{2}{*}{ א-casein genotypes } & $\mathrm{AA}$ & 39 & $.8109^{\mathrm{a}}$ & .0349 \\
& $\mathrm{AB}$ & 35 & $.7352^{\mathrm{b}}$ & .0380 \\
\multirow{4}{*}{ Parity } & 1 & 21 & .6558 & .0418 \\
& 2 & 17 & .8282 & .0403 \\
& $3-4$ & 19 & .7880 & .0370 \\
& $5-7$ & 13 & .7975 & .0420 \\
& $8-9$ & 4 & .7956 & .0662 \\
\hline
\end{tabular}

${ }^{a, b}$ : The probability of the means with different superscripts with main effects was $P<0.0596$. 


\section{Genotype Effect of $\kappa$-casein}

\section{Acknowledgment}

We wish to thank Dr. K. CHIKUNI of National Food Research Insititue in Tukuba, for providing the $\kappa$-casein primers.

A part of this work was supported by grants from the Ito Foundation in 1993.

\section{References}

1) Alexander, L. T., A. F. Stewart, A. G. MaCKINLAY, T.V. Kapelinskaya, T.M. TKach and S.I. GORODENTSKY, Isolation and characterization of the bovine $\kappa$-casein gene. Eur. J. Biochem., 178 : 395-401. 1988.

2) Chikuni, K., S. Kageyama, T. Kolshikawa, S. KATO and K. OzUTSUMI, Identification of bovine $\kappa$-casein genotypes using polymerase chain reaction method. Anim. Sci. Technol. (Jpn), 62 : 654-659. 1991. (in Japanese)

3) Damiani, G., L. Ferretti, G. Rognoni and V. SGARAMELla, Restriction fragment length polymorphism analysis of $\kappa$-casein locus in cattle. Anim. Genet., 21 : 107-114. 1990.

4) HaRveY, W.R., User's Guide for LSMLMW. 159. Ohio State Univ., Columbus. 1977.

5) Komatsu, M., K. Yokouchi, T. ABe, S. Ozawa and K. KITAZAWA, Relationship between milk protein genotypes and milk production in Holstein and Jersey cattle. Jap. J. Zootech. Sci., $52:$ 493-497. 1981. (in Japanese)

6) Levezilel, H., L. Metenier, M.F. Mahe, J. Choplane, J.P. Furet, G. Pabeuf, J.C. Mfrcier and F. GRosclaude, Identification of the two common alleles of the bovine $\kappa$-casein locus by the RFLP technique, using the enzy me Hind III. Genet. Sel. Evol., 20 : 247-254. 1988.

7) Rando, A., P. Digregorio and P. Masina, Identification of bovine $\kappa$-casein genotypes at the DNA level. Anim. Genet., 19 : 51-54. 1988.

8) Shimada. K., Y. Izaike, O. Suzuki, A. Okano, N. Takenouchi, $K$. Ohshima, T. Olshi, M. Kosugiyama and M. Takahashi, Research on milk yield nursing ability in Japanese Black (Wagyu) cows. Bull. Chugoku Natl. Agric. Exp. Stn., $12: 57-123$. 1993. (in Japanese) 